\title{
Brief Report \\ Effect of Temperature on the Germination of Five Coastal Provenances of Nothofagus glauca (Phil.) Krasser, the Most Representative Species of the Mediterranean Forests of South America
}

\author{
Rómulo E. Santelices-Moya ${ }^{1}$, Marta González Ortega ${ }^{2}$, Manuel Acevedo Tapia ${ }^{2} \mathbb{D}$, Eduardo Cartes Rodríguez ${ }^{2}$ \\ and Antonio M. Cabrera-Ariza ${ }^{3, * \mathbb{D}}$ \\ 1 Centro de Desarrollo del Secano Interior, Facultad de Ciencias Agrarias y Forestales, \\ Universidad Católica del Maule, Talca 3466706, Chile; rsanteli@ucm.cl \\ 2 Centro Tecnólogico de la Planta Forestal, Instituto Forestal Sede Biobío, Camino a Coronel Km 7.5, \\ San Pedro de la Paz 4130000, Chile; mgonzale@infor.cl (M.G.O.); macevedo@infor.cl (M.A.T.); \\ ecartes@infor.cl (E.C.R.) \\ 3 Centro de Investigación y Estudios Avanzados del Maule, Vicerrectoría de Investigación y Postgrado, \\ Universidad Católica del Maule, Talca 3466706, Chile \\ * Correspondence: acabrera@ucm.cl
}

check for

updates

Citation: Santelices-Moya, R.E.

González Ortega, M.;

Acevedo Tapia, M.

Cartes Rodríguez, E.;

Cabrera-Ariza, A.M. Effect of

Temperature on the Germination of

Five Coastal Provenances of

Nothofagus glauca (Phil.) Krasser, the Most Representative Species of the

Mediterranean Forests of South

America. Plants 2022, 11, 297.

https://doi.org/10.3390/

plants11030297

Academic Editors: Sofia Rhizopoulou, Maria Karatassiou and Efi Levizou

Received: 12 January 2022

Accepted: 21 January 2022

Published: 24 January 2022

Publisher's Note: MDPI stays neutral with regard to jurisdictional claims in published maps and institutional affiliations.

Copyright: (C) 2022 by the authors. Licensee MDPI, Basel, Switzerland. This article is an open access article distributed under the terms and conditions of the Creative Commons Attribution (CC BY) license (https:// creativecommons.org/licenses/by/ $4.0 /)$.

\begin{abstract}
Temperature is one of the most important abiotic factors affecting seed germination, and it is strongly influenced by local site conditions. Seeds of Nothofagus glauca, an endemic and vulnerable species of the Mediterranean region of Chile and the most representative of the Mediterranean forests of South America, were collected. In this study, we evaluated the effect of temperature on different germinative attributes of five $N$. glauca provenances representative of their natural distribution. The seeds were treated at a constant temperature (i.e., $18{ }^{\circ} \mathrm{C}, 22^{\circ} \mathrm{C}, 26^{\circ} \mathrm{C}$, or $30{ }^{\circ} \mathrm{C}$ ) in the absence of light for 40 days. The results show that in all the provenances, the germination ratio and energy increase linearly with temperature until reaching an optimum temperature (i.e., $22^{\circ} \mathrm{C}$ ), above which they decrease severely. At $22^{\circ} \mathrm{C}$, the response of average germination speed and germination vigor was significantly higher than with the other temperatures (performance of germination start day was not clear). The base temperature was around $18^{\circ} \mathrm{C}$ and the maximum, above $30{ }^{\circ} \mathrm{C}$, which may be close to thermo-inhibition. Given the threat of climate change, it is necessary to increase research in terms of the possible adaptation of this species to increased temperatures and prolonged periods of drought
\end{abstract}

Keywords: hualo; Mediterranean plants; seeds

\section{Introduction}

Nothofagus glauca (Phil.) Krasser (common name, hualo or roble maulino) is an endemic species of Central Chile that belongs to the Nothofagaceae family and is the most representative of the Mediterranean forests of its genus in South America. It is a deciduous, monoecious tree that can reach up to $30 \mathrm{~m}$ in height and $2 \mathrm{~m}$ in diameter [1], although at present it is difficult to find individuals that are more than $40 \mathrm{~cm}$ in diameter. The species is listed as vulnerable, and its populations are currently severely fragmented and trending toward decreasing [2].

The $N$. glauca forests have a discontinuous distribution in a latitudinal range of about $400 \mathrm{~km}$, from $33^{\circ} 58^{\prime} \mathrm{S}, 71^{\circ} 05^{\prime} \mathrm{W}$ to $37^{\circ} 27^{\prime} \mathrm{S}, 71^{\circ} 58^{\prime} \mathrm{W}$, although they are mostly concentrated in the Maule Region [3]. They are a transitional system between xerophytic formations and the southernmost temperate forests. This type of deciduous forest has adapted to the prolonged dry periods of summer and plays very important roles in the conservation of water and organic soil and in the biogeochemical carbon cycle as well as offering a great variety of ecological niches and habitats to the flora, fauna, and associated microbiota [4]. The 
natural range of this species has been considered a hotspot of biodiversity for conservation and is characterized by a great diversity of endemic species, although this has decreased to critical levels in terms of dominance and variability mainly because of anthropogenic factors [5]. The highest population density in Chile is concentrated in N. glauca distribution area, with the consequent pressure on natural resources, including the N. glauca forests.

The anthropogenic pressure has strongly shaped the landscape in the natural distribution area of $N$. glauca in recent years, affecting its spatial distribution, among other variables. Forty-five years ago, Urzúa [6] reported that there were 900,000 ha of these forests, whereas today, there are only 157,000 ha [3]. Another threat looming over these and other forests in the region is global climate change. Indeed, an increase in both temperatures and prolonged periods of drought has been recorded, factors that predispose the vegetation to being more prone to damage caused by biotic and abiotic agents. As an example, it can be noted that in the summer of 2017, 184,000 ha of the forest were consumed in a single fire, which affected an important part of this forest system [7]. In addition, considering that its regeneration by natural seeding is currently almost nonexistent, it is necessary to study its propagation by seeds to provide the necessary background to produce plants intended for afforestation and/or restoration of its populations. It is also important to consider the temperatures that limit the germination of seeds, especially if climate change is a factor that is affecting ecosystems.

Temperature is a crucial factor in the germination process of seeds [8]. It plays an important role in determining the periodicity of seed germination and the distribution of species (among other factors, it affects enzymatic activity) [9]. The germination rate generally increases linearly with temperatures up to an optimum temperature; subsequently, germination decreases severely with higher temperatures. Moreover, in the seed germination process, there are three levels of temperature: minimum, optimal, and maximum. The minimum, or base, temperature is the lowest temperature at which the seeds can germinate. The optimum temperature is the temperature at which the seeds reach their highest germination rate, and the maximum, or ceiling, temperature is the temperature above which the seeds cannot germinate [10]. The germination rate will increase between the minimum and optimum temperatures, whereas temperatures ranging from optimum to maximum will lead to a decrease in this attribute [11]. If the temperature is changing because of global climate change, it is evident that some species will have to adapt to these new environmental conditions, among other aspects, in the germination process.

$N$. glauca is a species whose seed production cycles are becoming longer, with years without seed production (unpublished data) and has seeds that present endogenous dormancy. There are mechanisms to break this condition, for example, through variable stratification periods at $4{ }^{\circ} \mathrm{C}$ (i.e., between 4 and 6 weeks) or by soaking them in gibberellic acid in concentrations from 0.1 to $0.8 \mathrm{~g} \mathrm{~L}^{-1}$ [12], reaching a germination ratio even above $95 \%$ using only viable seeds. However, the germination percentage may be different depending on the origin of the seeds [13]. Until today, no report has been made on the effect of temperature on the germination of any population of $N$. glauca. Therefore, this study aimed to analyze the effect of temperature in the germination process of seeds from five coastal provenances of $N$. glauca.

\section{Results}

The results show that temperature has a significant effect on the germination of N. glauca seeds from different provenances (Table 1, Figures 1 and 2). In all the provenances, the highest germination percentage was obtained at $22{ }^{\circ} \mathrm{C}$, although very different values were recorded in the germination ratio, from $34.0 \pm 0.6 \%$ in the Los Ruiles provenance to $78 \pm 0.3 \%$ in the Las Cañas provenance, observing the same tendency in the germinative energy. In general, in the northernmost provenances, a higher germination ratio was observed. These results show that $N$. glauca has a significant germination potential at $22{ }^{\circ} \mathrm{C}$. In addition, the highest slope in the germination curves was observed at this temperature (Figure 2), which is an indicator that with endogenous application of gibberellic 
acid at $22{ }^{\circ} \mathrm{C}$, latency is better overcome; it could be considered, then, that the optimum germination temperature for most provenances of $N$. glauca is around $22{ }^{\circ} \mathrm{C}$ (in the Las Cañas provenance, there were no significant differences between $22{ }^{\circ} \mathrm{C}$ and $26{ }^{\circ} \mathrm{C}$ ).

Table 1. Effect of temperature on different germination parameters of Nothofagus glauca (mean $\pm \mathrm{SE}$ ). Different letters indicate significant differences by Tukey's multiple comparison test $(p<0.05)$.

\begin{tabular}{ccccccc}
\hline Provenance & $\begin{array}{c}\text { Temperature } \\
\left({ }^{\circ} \mathbf{C}\right)\end{array}$ & $\begin{array}{c}\text { Germination } \\
\text { Ratio (\%) }\end{array}$ & $\begin{array}{c}\text { Germination } \\
\text { Energy (\%) }\end{array}$ & $\begin{array}{c}\text { Germination } \\
\text { Start Day }\end{array}$ & $\begin{array}{c}\text { Average Germination } \\
\text { Speed (Seed/Day) }\end{array}$ & $\begin{array}{c}\text { Germination } \\
\text { Vigor }\end{array}$ \\
\hline \multirow{6}{*}{ Licantén } & 18 & $6.7 \pm 0.67 \mathrm{~d}$ & $6.8 \pm 0.33 \mathrm{~d}$ & $25.0 \pm 0.0 \mathrm{c}$ & $0.1 \pm 0.22 \mathrm{c}$ & $0.0 \pm 0.0 \mathrm{~d}$ \\
& 22 & $52.0 \pm 0.01 \mathrm{a}$ & $45.0 \pm 2.26 \mathrm{a}$ & $11.0 \pm 0.94 \mathrm{a}$ & $1.5 \pm 0.07 \mathrm{a}$ & $2.4 \pm 0.11 \mathrm{a}$ \\
& 26 & $32.0 \pm 0.01 \mathrm{~b}$ & $31.4 \pm 1.44 \mathrm{~b}$ & $16.0 \pm 0.94 \mathrm{~b}$ & $0.7 \pm 0.03 \mathrm{~b}$ & $0.9 \pm 0.04 \mathrm{~b}$ \\
& 30 & $20.7 \pm 0.67 \mathrm{c}$ & $14.6 \pm 0.71 \mathrm{c}$ & $13.0 \pm 0.47 \mathrm{ab}$ & $0.6 \pm 0.03 \mathrm{~b}$ & $0.4 \pm 0.02 \mathrm{c}$ \\
\hline \multirow{6}{*}{ Las Cañas } & 18 & $10.7 \pm 0.54 \mathrm{c}$ & $6.2 \pm 0.11 \mathrm{c}$ & $24.3 \pm 0.27 \mathrm{~b}$ & $0.2 \pm 0.01 \mathrm{~d}$ & $0.1 \pm 0.0 \mathrm{~d}$ \\
& 22 & $78.7 \pm 0.54 \mathrm{a}$ & $77.1 \pm 3.42 \mathrm{a}$ & $12.0 \pm 0.94 \mathrm{a}$ & $2.4 \pm 0.11 \mathrm{a}$ & $9.1 \pm 0.41 \mathrm{a}$ \\
& 26 & $65.3 \pm 0.54 \mathrm{a}$ & $57.5 \pm 2.97 \mathrm{a}$ & $10.7 \pm 0.72 \mathrm{a}$ & $1.7 \pm 0.08 \mathrm{~b}$ & $4.0 \pm 0.2 \mathrm{~b}$ \\
& 30 & $22.7 \pm 0.54 \mathrm{~b}$ & $14.0 \pm 0.65 \mathrm{~b}$ & $12.0 \pm 0.47 \mathrm{a}$ & $0.7 \pm 0.04 \mathrm{c}$ & $0.6 \pm 0.03 \mathrm{c}$ \\
\hline \multirow{6}{*}{ Los Ruiles } & 18 & $0.7 \pm 0.54 \mathrm{~d}$ & $0.7 \pm 0.54 \mathrm{~d}$ & $0.0 \pm 0.0 \mathrm{c}$ & $0.0 \pm 0.0 \mathrm{~d}$ & $0.0 \pm 0.0 \mathrm{~d}$ \\
& 22 & $34.0 \pm 0.0 \mathrm{a}$ & $31.2 \pm 0.0 \mathrm{a}$ & $16.0 \pm 0.94 \mathrm{ab}$ & $0.8 \pm 0.04 \mathrm{a}$ & $1.3 \pm 0.05 \mathrm{a}$ \\
& 26 & $23.3 \pm 0.54 \mathrm{~b}$ & $19.3 \pm 0.9 \mathrm{~b}$ & $21.0 \pm 0.94 \mathrm{~b}$ & $0.5 \pm 0.02 \mathrm{~b}$ & $0.5 \pm 0.03 \mathrm{~b}$ \\
& 30 & $8.7 \pm 0.54 \mathrm{c}$ & $6.7 \pm 0.49 \mathrm{c}$ & $14.0 \pm 0.47 \mathrm{a}$ & $0.3 \pm 0.01 \mathrm{c}$ & $0.2 \pm 0.02 \mathrm{c}$ \\
\hline \multirow{6}{*}{ Curanipe } & 18 & $8.0 \pm 0.94 \mathrm{~d}$ & $8.0 \pm 0.42 \mathrm{~b}$ & $24.3 \pm 1.19 \mathrm{~b}$ & $0.1 \pm 0.01 \mathrm{~d}$ & $0.0 \pm 0.0 \mathrm{~d}$ \\
& 22 & $40.7 \pm 0.54 \mathrm{a}$ & $34.6 \pm 1.62 \mathrm{a}$ & $12.0 \pm 0.47 \mathrm{a}$ & $1.3 \pm 0.06 \mathrm{a}$ & $2.3 \pm 0.11 \mathrm{a}$ \\
& 26 & $34.0 \pm 0.0 \mathrm{~b}$ & $34.0 \pm 0.0 \mathrm{a}$ & $13.0 \pm 0.47 \mathrm{a}$ & $0.8 \pm 0.03 \mathrm{~b}$ & $1.3 \pm 0.06 \mathrm{~b}$ \\
& 30 & $13.3 \pm 0.54 \mathrm{c}$ & $8.1 \pm 0.38 \mathrm{~b}$ & $14.0 \pm 0.47 \mathrm{a}$ & $0.4 \pm 0.02 \mathrm{c}$ & $0.2 \pm 0.01 \mathrm{c}$ \\
\hline
\end{tabular}
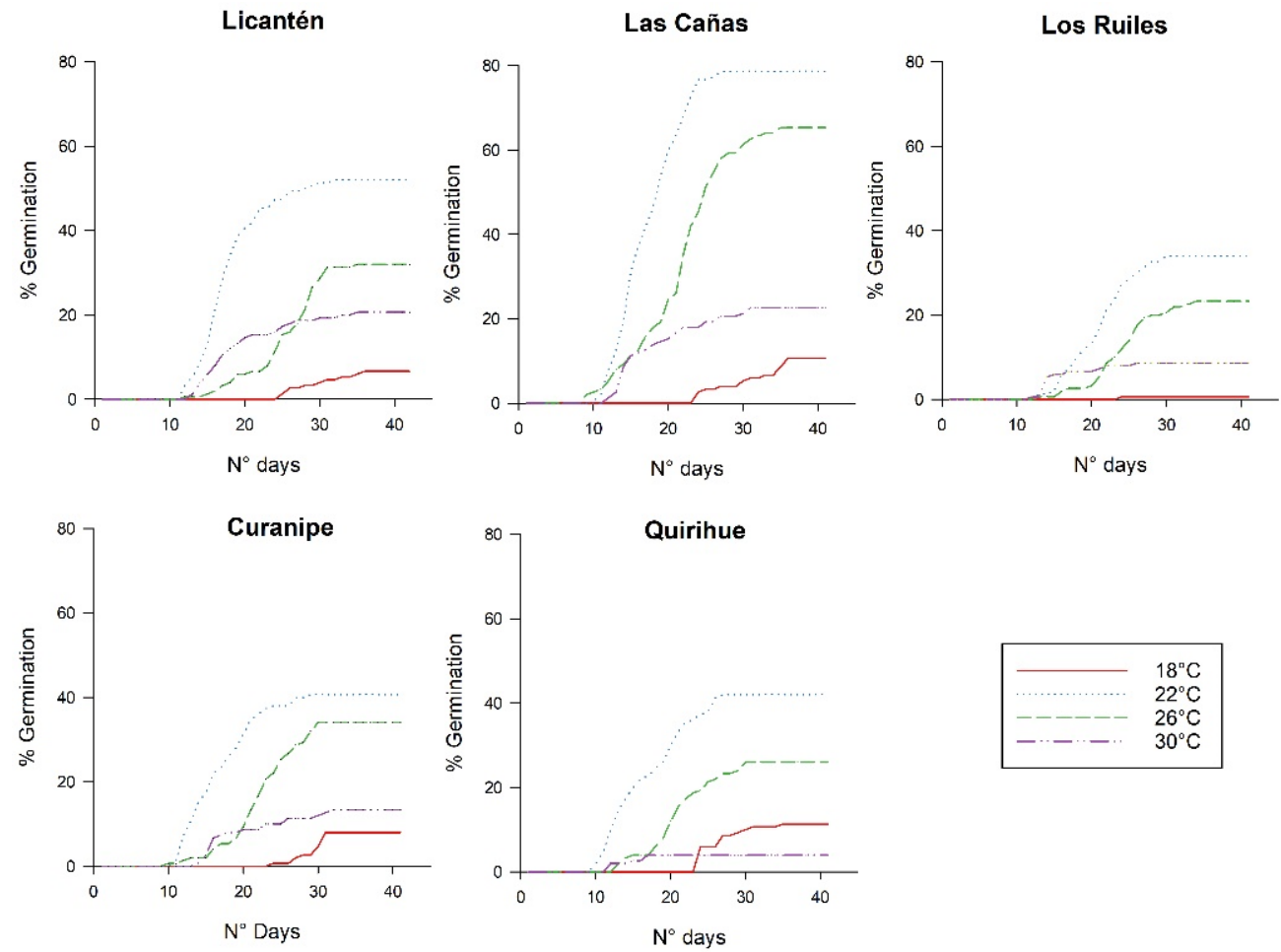

Figure 1. Cumulative germination percentage during 40 days for five Nothofagus glauca provenances treated at different temperatures in the absence of light. 


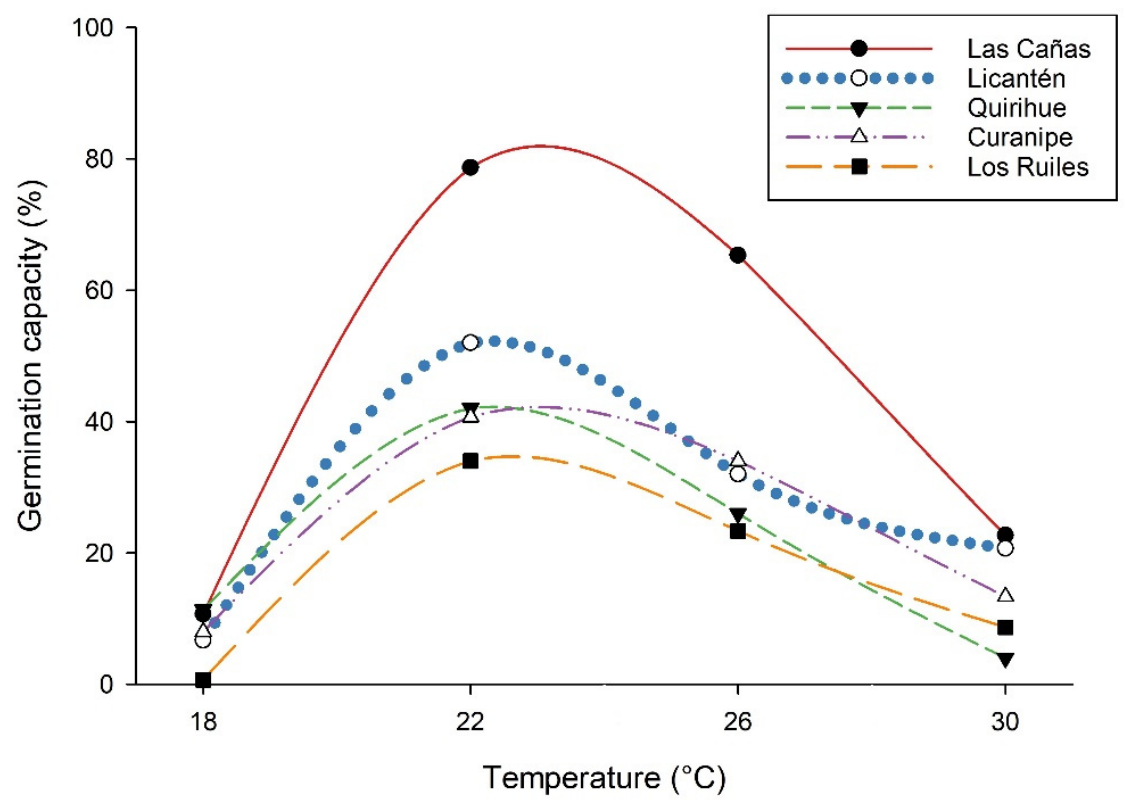

Figure 2. Final germination percentage of five provenances of Nothofagus glauca seeds treated at different temperatures in the absence of light.

In most of the provenances, once the seeds had begun to germinate, higher temperatures stimulated germination to an optimum temperature $\left(22^{\circ} \mathrm{C}\right)$, after which at $26^{\circ} \mathrm{C}$ and $30^{\circ} \mathrm{C}$, the germination rate decreased. A clear pattern was also observed on the germination start day because of temperature, although seeds treated at $18{ }^{\circ} \mathrm{C}$ generally took longer to germinate. In general, average germination speed and vigor were higher at $22{ }^{\circ} \mathrm{C}$, to later decrease with increasing temperatures; at $18{ }^{\circ} \mathrm{C}$ the lowest values were recorded in these two variables, although in some provenances, no significant differences were observed regarding those seeds treated at the highest temperature $\left(30^{\circ} \mathrm{C}\right)$.

\section{Discussion}

Seed germination is a process in which endogenous and exogenous factors intervene. On the one hand, two growth regulators that play a fundamental role in this process are gibberellic acid, a promoter of germination, and abscisic acid (ABA), which is an inhibitor. On the other hand, in addition to humidity and oxygen availability, temperature is the environmental factor with the greatest effect on the germination process of seeds, directly affecting their metabolism and germination speed [8]. With super-optimal temperatures, seed germination is delayed because a high level of ABA is maintained in the embryo and endosperm and the synthesis of gibberellic acid is suppressed [14,15]. The results of our research show a significant drop in germination at $30^{\circ} \mathrm{C}$, and it is likely that above this temperature, the seeds of $\mathrm{N}$. glauca approach the thermo-inhibition process and prevent gibberellin biosynthesis.

The cardinal temperatures for germination are related to the environmental range of adaptation of a particular species and serve to match the germination time with the favorable conditions for the growth and subsequent development of the seedlings [10]. In our research in all the provenances studied, it was observed that from $18{ }^{\circ} \mathrm{C}$, as the temperature increased, so did the germination until reaching a maximum at $22^{\circ} \mathrm{C}$, and then decreased. Thus, the optimum germination temperature for $N$. glauca would be at $22{ }^{\circ} \mathrm{C}$, whereas the minimum, or basal, temperature would be around $18{ }^{\circ} \mathrm{C}$, and the maximum, or ceiling, temperature would be above $30^{\circ} \mathrm{C}$. While the optimum temperature germination rate may vary between seed lots of the same species as a result of different genetic and environmental conditions [9], in the five provenances of N. glauca, this was not the case; the optimum temperature was clearly $22^{\circ} \mathrm{C}$, although for the Las Cañas provenance, it would be between $22{ }^{\circ} \mathrm{C}$ and $26^{\circ} \mathrm{C}$. It is striking that in the Los Ruiles provenance (area 
protected by the state), germination at $18{ }^{\circ} \mathrm{C}$ was practically null and the basal temperature for that provenance would likely be above that level. In the case of the southernmost provenance (Quirihue), at $30{ }^{\circ} \mathrm{C}$, germination fell to levels below those reached at $18{ }^{\circ} \mathrm{C}$; in this case, it would likely be closer to thermo-inhibition at that temperature. According to these results, it is probable that there is a genetic effect that conditions the germination process of the seeds.

Temperature not only plays a fundamental role in capacity and energy germination, but it also affects the germination start day, average germination speed, and germination vigor (Table 2). Once the seed has been rehydrated after imbibition, under suitable temperature conditions, physiological processes are triggered that allow the germination process to develop [8]. Although germination occurred at $18{ }^{\circ} \mathrm{C}$, with variable rates according to the geographic origin of the seeds, the process is significantly slower at that temperature, taking at least 24 days to begin germination; instead, with the optimum temperature (i.e., $22{ }^{\circ} \mathrm{C}$ ), it begins in some cases at 12 days. This same trend is also observed in both the average germination speed and vigor, meaning that the germination process of N. glauca is strongly conditioned by temperature. The germination ratio at the optimal temperature (i.e., $22^{\circ} \mathrm{C}$ ), is in the range found by other authors for the same species [12,13].

Table 2. Geographic and climatic data for provenances sampled.

\begin{tabular}{cccccc}
\hline Provenance & Latitude & Longitude & $\begin{array}{c}\text { Elevation } \\
\text { (m a.s.1.) }\end{array}$ & $\begin{array}{c}\text { M.A.T } \\
\left({ }^{\circ} \mathbf{C}\right)\end{array}$ & $\begin{array}{c}\text { M.A.R }^{2} \\
\left(\mathbf{m m} \text { Year }^{-1}\right)\end{array}$ \\
\hline Licantén & $34^{\circ} 55^{\prime} 49^{\prime \prime} \mathrm{S}$ & $72^{\circ} 5^{\prime} 11^{\prime \prime} \mathrm{W}$ & 403 & 12.5 & 829 \\
Las Cañas & $35^{\circ} 27^{\prime} 27^{\prime \prime} \mathrm{S}$ & $72^{\circ} 28^{\prime} 11^{\prime \prime} \mathrm{W}$ & 165 & 12.9 & 831 \\
Los Ruiles & $35^{\circ} 50^{\prime} 2^{\prime \prime} \mathrm{S}$ & $72^{\circ} 30^{\prime} 36^{\prime \prime} \mathrm{W}$ & 202 & 12.4 & 851 \\
Curanipe & $35^{\circ} 51^{\prime} 24^{\prime \prime} \mathrm{S}$ & $72^{\circ} 37^{\prime} 13^{\prime \prime} \mathrm{W}$ & 129 & 13.1 & 817 \\
Quirihue & $36^{\circ} 2^{\prime} 18^{\prime \prime} \mathrm{S}$ & $72^{\circ} 36^{\prime} 35^{\prime \prime} \mathrm{W}$ & 342 & 12.0 & 898 \\
\hline
\end{tabular}

${ }^{1}$ M.A.T.: mean annual temperature; ${ }^{2}$ M.A.R.: mean annual rainfall.

In the northernmost provenances, a higher percentage of germination was recorded, although no relationship was observed with the weight and morphometric characteristics of the seeds. In other species of the genus Nothofagus, it has been observed that the larger and heavier seeds have a greater germination ratio than those that are smaller and lighter, observing a clinal variation, although in a broader latitudinal distribution than that of this study [16]. This pattern was not observed in our study.

All species have a temperature range in which the germination process occurs. It has been described that for $N$. glauca, this range is likely between $10{ }^{\circ} \mathrm{C}$ and $30{ }^{\circ} \mathrm{C}$ [17]. On the one hand, in our research, we observed that the minimum temperature would be around $18{ }^{\circ} \mathrm{C}$, especially for the Los Ruiles provenance, which is why it would be advisable to investigate the behavior of different provenances of this species under $18{ }^{\circ} \mathrm{C}$. On the other hand, at $30{ }^{\circ} \mathrm{C}$, germination strongly decreases, and above that level would be the maximum temperature and occurrence of thermo-inhibition. Consequently, temperatures under $18{ }^{\circ} \mathrm{C}$ and above $30^{\circ} \mathrm{C}$ in the germination process of $N$. glauca should be evaluated.

Temperature is one of the main environmental factors that regulate seed physiology across plant taxa [10]. Because of climate change (i.e., increased temperatures and prolonged periods of drought), plants in general are being subjected to greater water stress, and therefore, their physiological processes are being affected. In the Mediterranean region of Chile, where $N$. glauca is distributed, there has been a significant increase in extremely hot events affecting the average temperature, and a deficit in rainfall [18]. N. glauca is widely known for its strong tendency for alternate bearing, which severely affects the fruit yield from year to year, and it has been observed that the cycles in seed production are becoming longer, with years without seed production (unpublished data). Given the threat of climate change on the reproductive cycle of the species and considering the effect that temperature has on the germination of $N$. glauca seeds, it is urgent and necessary to study in greater depth the adaptation capacity that this species would have to these new 
environmental conditions. Santelices, Espinoza, Magni, Cabrera, Donoso, and Peña [13] reported that the intra-provenance variability of $N$. glauca is systematically greater than that of inter-provenance, indicating a high potential capacity of the species to adapt to climate change. However, these authors affirm that there are differences in germination between Andean and coastal origins (in our research, we evaluated only costal provenances); this reaffirms the need to deepen research on the potential adaptation of N. glauca to climate change and the capacity of the species to regenerate and self-perpetuate.

\section{Material and Methods}

\subsection{Seed Collection and Preparation}

In March 2017, mature seeds were collected from different provenances of N. glauca in the Maule Region of Chile (Table 3, Figure 3), except those from Licantén, which were collected in March 2015. Seeds were transported to the laboratory, where they were manually separated from the rest of the plant material and the damaged seeds were discarded; then, they were weighed, dried, and stored in the dark in glass containers in an environment at $4{ }^{\circ} \mathrm{C}$ until they were used (i.e., January 2020). The standards of the International Seed Testing Association (ISTA) were followed to characterize the seeds [19]. One hundred seeds were weighed separately for eight repetitions to determine the weight of the seeds, which was expressed as the average weight of 1000 seeds. Then, the average weight of 1000 seeds and its equivalence in number of seeds per kilogram were calculated. In addition, the dimerous seeds were measured for length and width, and the trimerous seeds for length, width, and thickness (Table 2). To break the dormancy, the seeds were soaked in a $200 \mathrm{mg} \mathrm{L}^{-1}$ gibberellic acid solution (Giberplus ${ }^{\circledR}$ Tabletas, Anasac Chile S.A., Santiago, Chile) for $24 \mathrm{~h}$ before starting the germination tests [12].

The mean annual precipitation and temperature were obtained from WorldClim (version 2) at a spatial resolution of $30 \mathrm{~s}\left(\sim 1 \mathrm{~km}^{2}\right)$ by interpolation of the records of meteorological stations from 1970 to 2000 [20].

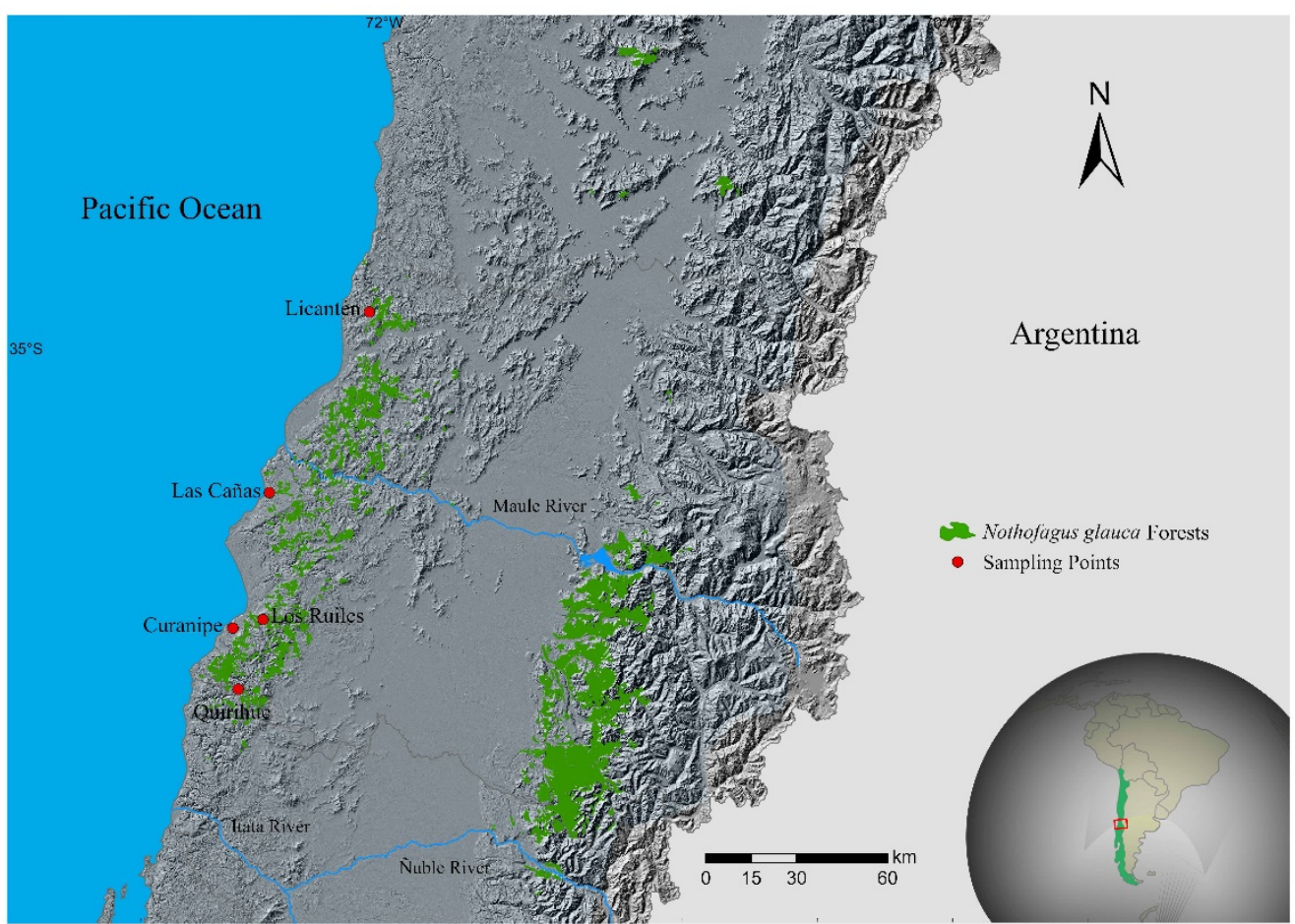

Figure 3. Seed provenances of Nothofagus glauca. 
Table 3. Weight and morphometric characterization of the seeds from five provenances of Nothofagus glauca (mean \pm Standard Error).

\begin{tabular}{cccccccc}
\hline \multirow{2}{*}{ Provenance } & $\begin{array}{c}\text { Weight of 1000 } \\
\text { Seeds } \mathbf{( g )}\end{array}$ & $\begin{array}{c}\text { Number of } \\
\text { Seeds per } \\
\text { Kilogram }\end{array}$ & Length $\mathbf{( m m )}$ & Width $(\mathbf{m m})$ & Lenght $(\mathbf{m m})$ & $\begin{array}{c}\text { Dimerous Seeds } \\
\text { Width (mm) }\end{array}$ & $\begin{array}{c}\text { Thickness } \\
(\mathbf{m m})\end{array}$ \\
\hline Licantén & $468.3 \pm 0.3$ & $2136 \pm 10.4$ & $17.1 \pm 1.8$ & $14.2 \pm 1.8$ & $17.2 \pm 0.1$ & $10.4 \pm 0.1$ & $9.7 \pm 0.1$ \\
Las Cañas & $537.5 \pm 0.4$ & $1861 \pm 14.0$ & $19.5 \pm 0.1$ & $12.1 \pm 0.2$ & $19.0 \pm 0.1$ & $10.8 \pm 0.1$ & $9.9 \pm 0.1$ \\
Los Ruiles & $683.7 \pm 0.5$ & $1463 \pm 10.3$ & $19.7 \pm 1.6$ & $13.2 \pm 1.8$ & $19.6 \pm 0.2$ & $11.3 \pm 0.2$ & $11.2 \pm 0.1$ \\
Curanipe & $395.5 \pm 0.3$ & $2530 \pm 9.9$ & $19.5 \pm 0.3$ & $11.3 \pm 0.2$ & $17.5 \pm 0.3$ & $10.3 \pm 0.1$ & $8.2 \pm 0.2$ \\
Quirihue & $379.0 \pm 0.4$ & $2641 \pm 14.9$ & $19.3 \pm 0.1$ & $12.1 \pm 0.1$ & $18.5 \pm 0.2$ & $9.7 \pm 0.1$ & $9.1 \pm 0.1$ \\
\hline
\end{tabular}

\subsection{Germination Experiments}

The study was carried out in a laboratory at the Universidad Católica del Maule, Talca, Chile $\left(35^{\circ} 26^{\prime} 10^{\prime \prime}\right.$ S, $71^{\circ} 37^{\prime} 13^{\prime \prime} \mathrm{W}, 131 \mathrm{~m}$ a.s.1.), during January and February 2020. The seeds were soaked in a Gibberellic Acid $\left(\mathrm{GA}_{3}\right)$ solution at $200 \mathrm{mg} \mathrm{L}^{-1}$ for $24 \mathrm{~h}$ using distilled water, and those that floated were excluded as they were considered unviable. To determine the effect of temperature on the germination of $N$. glauca seeds from different provenances, four different temperatures were tested: $18{ }^{\circ} \mathrm{C}, 22{ }^{\circ} \mathrm{C}, 26^{\circ} \mathrm{C}$, and $30{ }^{\circ} \mathrm{C}$. The cultivation was carried out in germinating chambers in the absence of light, maintaining fixed temperatures according to each treatment and using filter paper as the substrate. To not interfere with the treatments, the ambient temperature of the laboratory was constantly maintained below $16^{\circ} \mathrm{C}$. Irrigation was manual, and care was taken that the seeds were always wet.

The germination process was monitored daily until germination ceased over a period of 40 days. Seeds were considered to have germinated when the emerging radicles were over $2 \mathrm{~mm}$ long. The following germination parameters, adapted from [21,22], were calculated:

$$
\mathrm{GR}=\left[\frac{\mathrm{Sg}}{\mathrm{Ss}}\right] \times 100
$$

Germination ratio (GR) (1): represents the final percentage of seeds that germinate (Sg) in relation to the total number of seeds sown (Ss):

Germination energy (GE): accumulated percentage of germination on the day when the maximum value occurs (maximum value is maximum ratio from cultivated germination percentage on day $\mathrm{X}$ divided by $\mathrm{X}$ ).

Germination start day (GSD): the time elapsed from the sowing of the seeds to the germination of $5 \%$ of the sown seeds.

Average germination speed (AGS) [2]: corresponds to the average number of germinated seeds per day, calculated by the expression:

$$
\mathrm{AGS}=\sum_{1}^{k} \frac{n i}{t i}
$$

where $n i$ corresponds to the number of seeds germinated in the $i$ th data collection, $t i$ is the time (in days) of the $i$ th data collection, and $k$ is the time (in days) of the germination test duration.

Germination vigor $(\mathrm{GV})$ : reflects in a single value the changes in the germination peak, the total germination, and the germination speed, calculated as the product between the maximum value and the average germination speed.

\subsection{Trial Design and Statistical Analysis}

There were two factors tested in the trial: temperature (four levels) and provenance (five levels). The factorial combination of 20 treatments $(4 \times 5)$ was replicated three times in a split-plot design. Fixed effects were randomly assigned within subplots (considering the homogeneity of the temperature, whole plots were not randomized). There were 50 viable 
seeds per factorial combination, giving a total of 150 seeds per treatment. Temperature was applied to the whole plots and provenance, to the subplots. The treatments imposed follow:

- Temperature: $18^{\circ} \mathrm{C}, 22^{\circ} \mathrm{C}, 26^{\circ} \mathrm{C}$, and $30^{\circ} \mathrm{C}$

- Provenance: Licantén, Las Cañas, Los Ruiles, Curanipe, and Quirihue

Analyses of variance (ANOVAs) and comparisons of the means were conducted using the general linear model (GLM) procedure from the statistical software SPSS for Windows (SPSS, Chicago, IL, USA). Mean values with significant differences were compared using the Tukey test at the 5\% significance level.

\section{Conclusions}

Based on the results of this research, it can be concluded that temperature is an abiotic factor that significantly affects the germination of N. glauca. In the absence of light conditions, the optimum germination temperature for all the provenances studied was $22{ }^{\circ} \mathrm{C}$. By maintaining the temperature at $18^{\circ} \mathrm{C}$, germination was induced, although at a low percentage. At $30^{\circ} \mathrm{C}$, the germination percentage was also low, and above this level is the maximum germination temperature and risk of thermo-inhibition.

Author Contributions: Conceptualization, R.E.S.-M.; methodology, R.E.S.-M. and A.M.C.-A.; software, R.E.S.-M. and A.M.C.-A.; validation, R.E.S.-M. and A.M.C.-A.; formal analysis, E.C.R.; investigation, R.E.S.-M. and A.M.C.-A.; resources, R.E.S.-M., M.G.O., M.A.T. and E.C.R.; data curation, R.E.S.-M. and A.M.C.-A.; writing-original draft preparation, R.E.S.-M.; writing-review and editing, A.M.C.-A., M.G.O., M.A.T. and E.C.R.; visualization, R.E.S.-M. and A.M.C.-A.; supervision, R.E.S.-M.; project administration, R.E.S.-M.; funding acquisition, R.E.S.-M., M.G.O., M.A.T. and E.C.R. All authors have read and agreed to the published version of the manuscript.

Funding: This research received no external funding.

Institutional Review Board Statement: Not applicable.

Informed Consent Statement: Not applicable.

Data Availability Statement: No new data were created or analyzed in this study. Data sharing is not applicable to this article.

Conflicts of Interest: The authors declare no conflict of interest.

\section{References}

1. Rodríguez, R.; Quezada, M. Fagaceae. In Flora de Chile 2; Marticorena, C., Rodríguez, R., Eds.; Universidad de Concepción: Concepción, Chile, 2003; pp. 64-76.

2. $\quad$ Barstow, M.; Rivers, M.C.; Baldwin, H. Nothofagus Glauca. IUCN Red List. Threat. Species 2017, eT32034A2809142. [CrossRef]

3. Santelices-Moya, R.; Vergara, R.; Cabrera-Ariza, A.; Espinoza-Meza, S.; Silva-Flores, P. Variación intra-específica en Nothofagus glauca una especie endémica de los bosques mediterráneos de Chile. Bosque 2020, 41, 221-231. [CrossRef]

4. Arroyo, M.T.K.; Riveros, M.; Peñaloza, A.; Cavieres, L.; Faggi, A.M. Phytogeographic relationships and regional richness patterns of the cool temperate rainforest flora of southern South America. In High-Latitude Rainforests and Associated Ecosystems of the West Coasts of the Americas: Climate, Hydrology, Ecology and Conservation; Lawford, R.G., Alaback, P.B., Fuentes, E., Eds.; Springer: New York, NY, USA, 1996; pp. 134-172.

5. Myers, N.; Mittermeier, R.A.; Mittermeier, C.G.; da Fonseca, G.A.B.; Kent, J. Biodiversity hotspots for conservation priorities. Nature 2000, 403, 853-858. [CrossRef] [PubMed]

6. Urzúa, A. Cambio de Estructura en el Bosque de Nothofagus glauca (Phil.) Krasser. Ph.D. Thesis, Universidad de Chile, Santiago, Chile, 1975; Tesis Ingeniería Forestal.

7. Valencia, D.; Saavedra, J.; Brull, J.; Santelices, R. Severidad del daño causado por los incendios forestales en los bosques remanentes de Nothofagus alessandrii Espinosa en la región del Maule de Chile. Gayana Botánica 2018, 75, 531-534. [CrossRef]

8. Baskin, C.C.; Baskin, J.M. Seeds: Ecology, Biogeography, and Evolution of Dormancy and Germination; Academic Press: San Diego, CA, USA, 2014; p. 1600.

9. Belmehdi, O.; El Harsal, A.; Benmoussi, M.; Laghmouchi, Y.; Senhaji, N.S.; Abrini, J. Effect of light, temperature, salt stress and $\mathrm{pH}$ on seed germination of medicinal plant Origanum elongatum (Bonnet) Emb. \& Maire. Biocatal. Agric. Biotechnol. 2018, 16, 126-131. [CrossRef]

10. Bewley, J.D.; Bradford, K.J.; Hilhorst, H.W.M.; Nonogaki, H. Seeds: Physiology of Development, Germination and Dormancy, 3rd ed.; Springer: New York, NY, USA, 2013; p. 392. 
11. Bradford, K.J. Applications of hydrothermal time to quantifying and modeling seed germination and dormancy. Weed Sci. 2002, 50, 248-260. [CrossRef]

12. Cabello, A.; Espinoza, N.; Espinoza, S.; Cabrera, A.; Santelices, R. Effect of pre-germinative treatments on Nothofagus glauca seed germination and seedling growth. N. Z. J. For. Sci. 2019, 49, 1-9. [CrossRef]

13. Moya, R.S.; Meza, S.E.; Díaz, C.M.; Ariza, A.C.; Calderón, S.D.; Peña-Rojas, K. Variability in seed germination and seedling growth at the intra- and inter-provenance levels of Nothofagus glauca (Lophozonia glauca), an endemic species of Central Chile. N. Z. J. For. Sci. 2017, 47, 10. [CrossRef]

14. Toh, S.; Imamura, A.; Watanabe, A.; Nakabayashi, K.; Okamoto, M.; Jikumaru, Y.; Hanada, A.; Aso, Y.; Ishiyama, K.; Tamura, N.; et al. High Temperature-Induced Abscisic Acid Biosynthesis and Its Role in the Inhibition of Gibberellin Action in Arabidopsis Seeds. Plant Physiol. 2008, 146, 1368-1385. [CrossRef] [PubMed]

15. Izydorczyk, C.; Nguyen, T.N.; Jo, S.; Son, S.; Tuan, P.A.; Ayele, B.T. Spatiotemporal modulation of abscisic acid and gibberellin metabolism and signalling mediates the effects of suboptimal and supraoptimal temperatures on seed germination in wheat (Triticum aestivum L.). Plant Cell Environ. 2018, 41, 1022-1037. [CrossRef] [PubMed]

16. Donoso, C. Variación Natural en Especies de Nothofagus en Chile. Bosque 1987, 8, 85-97. [CrossRef]

17. Buamscha, M.G.; Contardi, L.T.; Dumroese, R.K.; Enricci, J.A.; Escobar, R.; Gonda, H.E.; Jacobs, D.F.; Landis, T.D.; Luna, T.; Mexal, J.G.; et al. Producción de Plantas en Viveros Forestales; Contardi, L.T., Gonda, H.E., Tolone, G., Salimbeni, J., Eds.; Consejo Federal de Inversiones; Universidad Nacional de la Patagonia San Juan Bosco; Centro de Investigación y Extensión Forestal Andino: Patagonia, Argentina, 2012; p. 220.

18. DMC. Reporte Anual de la Evolución del Clima en Chile; Dirección Meteorológica de Chile: Santiago, Chile, 2020 ; p. 44.

19. ISTA. International Rules for Seed Testing; ISTA (International Seed Testing Association): Zurich, Switzerland, 2006.

20. Fick, S.E.; Hijmans, R.J. WorldClim 2: New 1-km spatial resolution climate surfaces for global land areas. Int. J. Climatol. 2017, 37, 4302-4315. [CrossRef]

21. Kamran, M.; Wang, D.; Xie, K.; Lu, Y.; Shi, C.; El Sabagh, A.; Gu, W.; Xu, P. Pre-sowing seed treatment with kinetin and calcium mitigates salt induced inhibition of seed germination and seedling growth of choysum (Brassica rapa var. parachinensis). Ecotoxicol. Environ. Saf. 2021, 227, 112921. [CrossRef] [PubMed]

22. Czabator, F.J. Germination value: An index combining speed and completeness of pine seed germination. For. Sci. 1962, 8 , 386-396. 